\title{
SOUTHERN METHODIST UNIVERSITY \\ RADIOCARBON DATE LIST II
}

\author{
HERBERT HAAS
}

Institute for the Study of Earth and Man, Southern Methodist University, Dallas, Texas 75275

and

VANCE HAYNES

Department of Anthropology, University of Arizona,

Tucson, Arizona 85721

\section{INTRODUCTION}

All samples described in this date list have been dated from November 1973 to January 1975. Only the benzene liquid scintillation installation was used during this time. For the combustion of soil and fossil bone samples containing a high content of sulfur (ie, in the form of pyrite), a new $\mathrm{CO}_{2}$ extraction and cleaning system was built. The gases released by the combustion are dried in ice and dry ice traps, passed through hot copper oxide and bubbled through $\mathrm{KOH}$ solution. Following the combustion, the $\mathrm{K}_{2} \mathrm{CO}_{3}$ precipitate is acidified in the same vessel where it formed and the released $\mathrm{CO}_{2}$ is again dried in a dry ice trap and by passing it through ascarite. This $\mathrm{CO}_{2}$ gas is quite clean and can be brought to the original system where the gas volume is measured. Further processing is as previously described (Haynes and Haas, 1974).

During 1974 numerous experiments were conducted to improve conversion yields as well as gas and benzene purity. This has led to changes in our procedures and publication of the details was delayed. Thus, our article on procedures and counting methods will be submitted for publication shortly.

For our present date list, we used the 5568 year half-life, $95 \%$ NBS oxalic acid activity and 1950 as reference for $\mathrm{AD} / \mathrm{BC}$ dates.

The description of each sample is based on information provided by the submitter.

\section{ACKNOWLEDGMENTS}

The laboratory is supported by the Institute for the Study of Earth and Man (ISEM) and by the National Science Foundation (Grant DES7201582 A01). The National Geographic Society is supporting archaeologic excavations at the Murray Springs and Lehner Ranch Clovis sites. Valuable technical assistance in the laboratory was provided by Nancy Neubert, Steven Haney, Bijan Rafipour and James Novak; secretarial work by Barbara Doolin.

\section{SAMPLE DESCRIPTIONS}

\section{GEOCHEMICAL SAMPLE}

\section{SMU-124. Ostrich egg shell}

(163.0 $\pm .8 \%)$ modern

Egg bought in market at Addis Ababa, Ethiopia in 1973 by $P$ Jeschofnig. Date is from carbonate of shell. 
II. GEOCHRONOLOGIC SAMPLES

\section{A. Arizona}

\section{Murray Springs Ranch series}

Outcropping of Unit $\mathrm{F}_{2}$ "black mat" in tributary gulley of Curry Draw on N side of Southern Pacific RR tracks opposite Murray home site $\left(31^{\circ} 34^{\prime} 30^{\prime \prime} \mathrm{N}, 110^{\circ} 10^{\prime} 07^{\prime \prime} \mathrm{W}\right)$ Cochise Co, Arizona. Coll 1970 by C V Haynes.

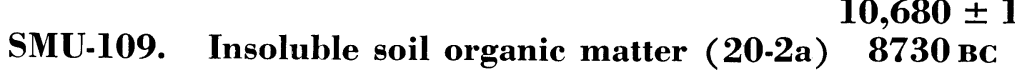

$$
10,680 \pm 140
$$

$9420 \pm 80$

SMU-130. Humates, 1st extraction $\left(20-2 \mathbf{b}_{1}\right) \quad 7470$ BC

\section{SMU-133. Humates, 2nd extraction $\left(\mathbf{2 0 - 2 b _ { 2 } )} \quad \mathbf{7 2 4 0 ~ B C}\right.$}

$9190 \pm 250$

Comment: date for insoluble residue is probably correct.

\section{Grass Circle trench series}

Circular depression $\left(31^{\circ} 33^{\prime} 40^{\prime \prime} \mathrm{N}, 110^{\circ} 10^{\prime} 05^{\prime \prime} \mathrm{W}\right)$ on pediment surface $1.4 \mathrm{~km} \mathrm{~S}$ of Murray Springs, Cochise Co, Arizona contains sediments and compound soils and supports .7ha desert grassland within area of Chihuahuan desert shrub. Coll 1968 by C V Haynes.

\section{SMU-91. Humates (1st extraction) 13-2B1}

$6540 \pm 190$

Lower of 2 samples of black soil coll .6m below surface at $20+00 \mathrm{E}$.

\section{SMU-92. Humates (2nd extraction) 13-2B2}

Comment: Does not agree with date of $4340 \pm 140$ (Tx-1175) on insoluble soil residue, which apparently could not be purified of contaminating plant matter.

\section{Double Adobe series}

Laminated marl overlying mammoth bones ca $400 \mathrm{~m} \mathrm{~S}$ of Double Adobe store in W bank of Whitewater Draw, Arizona $\left(31^{\circ} 28^{\prime} \mathrm{N}, 109^{\circ} 42^{\prime}\right.$ W). Coll and subm 1970 by C V Haynes.

\section{SMU-129. Marl carbonate$$
9730 \pm 100
$$$$
7780 \mathrm{BC}
$$ \\ SMU-128. Marl carbonate

$$
10,980 \pm 90
$$ \\ 9030 BC}

Comments $(\mathrm{HH})$ : marl was subm in a block measuring $14 \mathrm{~cm}$ across the laminae. A $2 \mathrm{~cm}$ slice was removed from each end for dating. (CVH): unfortunately sample orientation was lost in transit but presumably sample ages are consistent with top and bottom laminae. Dates are older than charcoal date of $8920 \pm 1150$ (Tx-1199) from underlying sand and gravel alluvium. A component of "dead" carbon in the aqueous environment is suggested. 
Cerros Negros marl series

Marl from Cerros Negros site, $6.4 \mathrm{~km}$ SE of San Manuel, Arizona $\left(32^{\circ}\right.$ $32^{\prime} \mathrm{N}, 110^{\circ} 33^{\prime} \mathrm{W}$ ). Coll and subm 1974 by J C Liddicoat. Samples listed in stratigraphic order from top to bottom of sec.

SMU-113. Marl \#3 carbonate

SMU-112. Marl \#2 carbonate

SMU-146. Marl \#2 organic residue

SMU-111. Marl \#1 carbonate

SMU-143. Marl \# 1 organic residue

Comments (CVH \& JCL): carbonate dates SMU-113 and -112 agree with previous results at Univ Texas (R, 1975, v 17, p 59-60) which may be minimum dates, but organic residues derived from pyrolyses are inconsistent and apparently contaminated (JCL): SMU-111 is not concordant with Tx-978 $(26,180 \pm 960)$ or Tx-974 $(27,410 \pm 1120)$.

\section{Lehner Ranch Arroyo series}

In 1974 archaeologic and geologic studies were renewed at Clovis mammoth-kill site on Lehner ranch $\left(31^{\circ} 25^{\prime} 23^{\prime \prime} \mathrm{N}, 110^{\circ} 06^{\prime} 48^{\prime \prime} \mathrm{W}\right)$ Cochise Co, Arizona. Coll and subm 1974 by C V Haynes except as indicated.

\section{SMU-93. Soil humates}

$4330 \pm 200$ 2380 BC

First and 2nd humate extractions, combined, from reddish-brown soil on Unit $\mathrm{G}_{2 \mathrm{a}}$ exposed in Trench B. Comment: date is consistent with stratigraphic position.

\section{SMU-175. Soil humates (9LS74)}

$9530 \pm 100$

Extracted from base of Donnet silt $\left(\right.$ Unit $\mathrm{F}_{3}$ ) overlying Cochise artifacts resting on top of Clanton clay $\left(\mathrm{Unit}_{2} \mathrm{~F}_{2}\right)$ in Sq $4 \mathrm{~W}, 10 \mathrm{~S}$. Comment: date is consistent with stratigraphic position.

SMU-204. Soil humates (10LS74)

$9900 \pm 80$ $7950 \mathrm{BC}$

Extracted from top of Clanton clay (Unit $\mathrm{F}_{2}$ ) immediately underlying Cochise artifacts in Sq 4W, 10S. Coll 1974 by Lisa Haynes. Comment: date is consistent with stratigraphic position.

\section{SMU-192. Charcoal (11LS74)}

$$
11,100 \pm 100
$$$$
9150 \text { BC }
$$

Sample coll from within Clanton clay $\left(U_{n i t} \mathrm{~F}_{2}\right.$ ) in $\mathrm{Sq} 4 \mathrm{~W}$, 10S. Coll 1974 by Norma Ajeman. Comment: date is Clovis age but within stratum overlying Clovis occupation surface possibly due to bioturbation. 
SMU-201. Humates from (12LS74)

Sample coll from Clovis occupation level in Sq 4S, 6W immediately under Clanton clay (Unit $\mathrm{F}_{2}$ ). Coll 1974 by James Mead. Comments $(\mathrm{CVH})$ : date is too young for Clovis occupation and is of the correct order for early Cochise occupation. No evidence of accidental interchange of this with SMU-192 could be found after careful review of all records. Intrusion via bioturbation is another possible explanation. $(\mathrm{HH})$ : extraction of humates from charcoal was complete with some dissolution of charcoal. Humate solution cleaned from charcoal dust by centrifugation.

\section{SMU-164. Charcoal (4LS74)}

$10,860 \pm 280$

Sample collected from Clovis occupation surface on $2 \mathrm{E}$ line between $3 \mathrm{~N}$ and $4 \mathrm{~N}$ immediately under Clanton clay $\left(\mathrm{Unit} \mathrm{F}_{2}\right)$. Comment: date is within range of known Clovis radiocarbon dates but on the young side.

\section{SMU-194. Charcoal (13LS74)}

$$
10,850 \pm 110
$$

Sample coll from Clovis occupation surface in Sqs 4W, 4, 6, and 8S. Comment: date is on young side of range of known Clovis radiocarbon dates.

SMU-196. Charcoal (13LS74)

$11,080 \pm 230$

9130 вс

Sample coll from Clovis occupation surface in Sqs 20S, 2W; 20S, 4W; 18S, 6W. Comment: date is consistent with known Clovis radiocarbon dates.

\section{SMU-168. Charcoal (3LS74)}

\section{SMU-195. Humates (3LS74)}

Sample from upper $10 \mathrm{~cm}$ of Graveyard channel sand $\left(\right.$ Unit $\left.F_{1}\right)$ over $\mathrm{E}$ area of site. Comments (CVH): date is on young side of range of known Clovis radiocarbon dates. Humates are same age, giving 10,820 \pm 130 as average of the 2 values. $(\mathrm{HH})$ : charcoal decayed to powder during $\mathrm{NaOH}$ treatment, separation of humates and charcoal is incomplete.

\section{SMU-181. Charcoal (6LS74)}

$11,080 \pm 200$

9130 BC

Sample from channel gravels of Graveyard member (Unit $F_{1}$ ). Coll 1974 by Lisa Huckel. Comment: date is within range of known Clovis dates. 
SMU-140. Trench G charcoal (1LS74)

SMU-158. Humates from (1LS74)

$$
\begin{aligned}
& 11,170 \pm 310 \\
& 9220 \mathrm{BC}
\end{aligned}
$$

$10,570 \pm 80$

Sample coll from right bank of middle fork of Lehner Ranch arroyo, $.4 \mathrm{~km}$ upstream from site. Comment: charcoal is of Clovis age but there is no evidence of culture.

\section{SMU-182. Trench G charcoal (7LS74)}

$10,940 \pm 170$

Sample coll by Herbert Haas from same location as SMU-140 but slightly higher in sec. Comment: similarity of SMU-140 and -182 confirms interpretation that alluvium here is an ancient reworked slump block.

\section{SMU-155. Trench F charcoal (2LS74)}

$$
\begin{aligned}
& 13,830 \pm 120 \\
& 11,880 \text { BC }
\end{aligned}
$$

\section{SMU-159. Trench F charcoal (8LS74)}

$$
13,860 \pm 120
$$

Samples coll from right bank of Lehner Ranch arroyo ca $50 \mathrm{~m} \mathrm{~W}$ of site in previously unmapped alluvial facies of a white marl. Comment: dates are within range of those for Coro marl at Murray Springs (Valastro et al, 1975; Haynes and Haas, 1974).

\section{Dent Clovis site series}

\section{B. Colorado}

Dent site, Weld Co, Colorado $\left(40^{\circ} 18^{\prime} 30^{\prime \prime} \mathrm{N}, 104^{\circ} 50^{\prime} 03^{\prime \prime} \mathrm{W}\right)$ is 1st Clovis mammoth-kill site discovered in America (1932) and bone organic matter previously dated $11,200 \pm 500$ (I-622). Test trench excavated in 1973 by Univ Colorado revealed charcoal and coke in silt matrix of the bones. Coll 1973 by Mike Nowak and subm 1973 by Frank Frazier.

\section{SMU-120. Charcoal and wood}

$$
\begin{array}{r}
170 \pm 50 \\
\text { AD } 1780
\end{array}
$$

\section{SMU-121. Coke}

$32,260 \pm 2100$ $\mathbf{3 0 , 3 1 0 ~ B C}$

Comment (CVH): supposed intrusion is now confirmed. Coke could be derived from Cretaceous coal beds in area and charcoal may indicate that redeposition occurred a century or more ago.

\section{SMU-136. Big Dry Creek}

Charcoal disseminated in clayey silt matrix at $4.7 \mathrm{~m}$ depth, ca $46 \mathrm{~cm}$ above bedrock/alluvium contact, ca $15 \mathrm{~m} \mathrm{~N}$ of Big Dry Creek, Lafayette Quad, Colorado (39 53' 34" N, $105^{\circ} 3^{\prime} 23^{\prime \prime}$ W). Coll Dec 1973 by M N Machette. 


\section{Guest site series}

\section{Florida}

Sample from a gastropod-bearing marl $3 \mathrm{~m}$ below surface of Spring Run at Silver Springs $\left(29^{\circ} 09^{\prime} \mathrm{N}, 82^{\circ} 09^{\prime} \mathrm{W}\right) 8 \mathrm{~km} \mathrm{E}$ of Ocala, Florida. Mammoth bones and small paleo-Indian projectile point occurred on marl and below interbedded organic and calcareous strata. Coll and subm 1973 by Charles Hoffman.

SMU-110. Marl carbonate

\section{SMU-115. Gastropod shell from marl}

Comment (CVH): gastropods apparently intruded upper part of marl before deposition of mammoth bones.

\section{Jones Bog series}

\section{Missouri}

Samples from Jones Bog, a "fossil" spring 1.6km ESE of Avery School, Missouri (38 $\left.03^{\prime} 25^{\prime \prime} \mathrm{N}, 93^{\circ} 20^{\prime} 22^{\prime \prime} \mathrm{W}\right)$. Coll and subm 1973 by $\mathrm{V}$ Haynes.

SMU.94. Upper peat (5Mo73)

SMU.96. 2nd humate extraction from (5Mo73)

$44,040 \pm 2660$ 42,090 BC

Sample, adjacent to mastodon tooth from upper of 2 buried peat lenses. Comment: dates indicate both peat layers are beyond limit of radiocarbon dating.

\section{SMU-99. Tusk filling (1Mo73)}

$31,130 \pm 1550$

Vegetable fibers from peat filling nerve canal of mastodon tusk in upper peat. Comment: date is probably minimum because of contamination by younger rootlets.

\section{Philips Ford Spring series}

Buried alluvial deposits of active spring on $8 \mathrm{~m}$ alluvial terrace of Pomme de Terre $\mathrm{R}$ at Philips Ford (38 $03^{\prime} 37^{\prime \prime} \mathrm{N}, 93^{\circ} 19^{\prime} 10^{\prime \prime} \mathrm{W}$ ) Hickory Co, Missouri contain archaic cultural material.

\section{SMU.98. Charcoal (9Mo73) \\ $4310 \pm 70$ \\ SMU-98. Charcoal (9Mo73) \\ $2360 \mathrm{BC}$ \\ SMU-102. Charcoal (9Mo73) culture.

Sample from hearth at $140 \mathrm{~cm}$ below terrace surface. Comment: dates 
SMU-193. Moss (23HI216)

Buried moss from 170 to $180 \mathrm{~cm}$ level. Comment: date applies to late stage of terrace aggradation but not assoc with culture.

\section{Lake Lahontan}

\section{E. Nevada}

Dendritic tufa head from top of Lake Lahontan Sehoo Farm in fresh wash on W side of Truckee R ca $1.6 \mathrm{~km} \mathrm{~N}$ of Univ Nevada S-S Ranch $\left(39^{\circ} 44^{\prime} \mathrm{N}, 119^{\circ} 19^{\prime} \mathrm{W}\right)$. Coll and subm by J C Liddicoat in Oct 1973.

\section{SMU-116. Tufa, carbonate}

$12,910 \pm 110$ 10,960 BC

SMU-137. Tufa, organic residue

$13,090 \pm 140$

Comments $(\mathrm{HH})$ : carbonate date was repeated with small sample, this check date agreed well with SMU-116. (JCL): tufa dates closely agree with ca 11,000-yr dates reported for stratigraphically equivalent tufa.

\section{North Sulphur River series}

$$
\text { F. Texas }
$$

Samples from alluvium underlying floodplain of $\mathrm{N}$ Sulphur $\mathrm{R}$ in vicinity of Ben Franklin, Delta Co, Texas. Subm by M Rainey, Southern Methodist Univ.

\section{SMU-122. Pelecypod shell}

$420 \pm 50$

Shell is modern from N Sulphur R $\left(33^{\circ} 28^{\prime} 30^{\prime \prime} \mathrm{N}, 95^{\circ} 46^{\prime} 30^{\prime \prime} \mathrm{W}\right)$. Coll and subm Feb 1974 by M Rainey. Comment (HH): demonstrates that animal absorbed bicarbonate that is partly derived from dissolution of old carbonates (Cretaceous chalk); shell dates from area can be expected to be too old.

\section{SMU-126. Mussel shells}

$$
10,320 \pm 110
$$

Shells from Sulphur R formation (33० $\left.28^{\prime} 50^{\prime \prime} \mathrm{N}, 95^{\circ} 47^{\prime} \mathrm{W}\right)$, $\mathrm{Q}_{\mathrm{sr} 2}$ (Slaughter and Hoover, 1963), 60cm above stream bed. Coll April 1974 by M Rainey and C V Haynes. Comment $(\mathrm{HH})$ : shell fragments soft and friable, dispersed in clayey soil.

\section{SMU-125. Mussel shells}

$11,270 \pm 110$

9320 вс

Shells from $3 \mathrm{~m}$ above stream bed in $\mathrm{Q}_{\mathrm{sr} 2}\left(33^{\circ} 28^{\prime} 50^{\prime \prime} \mathrm{N}, 95^{\circ} 47^{\prime} \mathrm{W}\right)$. Coll April 1974 by M Rainey and C V Haynes. See comment for SMU-126.

\section{SMU-131. Carbonized wood}

$1570 \pm 60$

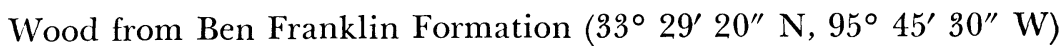
which overlies Sulphur R formation (Rainey, 1974). Comment (HH): 
date fits well with other dates from same formation, $1790 \pm 50$, charcoal, SMU-71 (R, 1974, v 16, p 375) and $1833 \pm 144$, clam shells (SM-599).

$$
\text { G. Mexico }
$$

\section{SMU-101. Tlapacoya I}

$23,210 \pm 330$

Wood fragments, SE side of Cerro Tlapacoya, a hill $28 \mathrm{~km}$ SE of Mexico City's Plaza de Constitucion and just $\mathrm{N}$ of Mexico City-Puebla Toll Rd (19 $\left.17^{\prime} 30^{\prime \prime} \mathrm{N}, 98^{\circ} 55^{\prime} 00^{\prime \prime} \mathrm{W}\right)$. From SW wall of Trench $\alpha$ at $17.7 \mathrm{~m}$ from $.0 \mathrm{~m}$. Coll in woody peat layer .3 to $2 \mathrm{~cm}$ thick, 65 to $67 \mathrm{~cm}$ below Unit 3/Unit 4 contact; appears to be Limbrey's Unit 3. Base of woody peat 3 to $4 \mathrm{~cm}$ above top of J L Liddicoat paleomagnetic sample M3-B3. Coll and subm Dec 1973 by P W Lambert, US Geol Survey, Federal Center, Denver, Colorado.

$$
\text { H. Egypt }
$$

\section{SMU-123. Gebel Silsila 2B, I}

$13,240 \pm 130$

Unio shells, Kom Ombo Plain (24 $37^{\prime} \mathrm{N}, 32^{\circ} 56^{\prime} \mathrm{E}$ ) Level 3, Afian culture. Coll Feb 1963 by M Baumhoff and subm by J L Phillips, Dept Anthropol, Univ Illinois at Chicago Circle, Illinois. Comment: Level 3 overlies Level 2, which has 2 dates: $13,070 \pm 160$ and 13,560 \pm 120 (Y-1375 and -1447: R, 1969, v 11, p 642).

\section{ARCHAEOLOGIC SAMPLES}

\section{A. Ethiopia}

Charcoal and burned bone (?) samples from Red Stone Hill, Rift Valley Lake Area, $\left(38^{\circ} 43^{\prime} \mathrm{N}, 7^{\circ} 47^{\prime} \mathrm{E}\right)$. Coll June 1971 and subm by $\mathrm{J}$ Gallagher, Dept Anthropol, El Centro College, Dallas, Texas.

SMU.89. E 71-5, Loc 1

From cave, Test Pit \#1, mixed $5 \mathrm{~cm}$ levels.

SMU-88. E 71-5, Loc 2

From rock shelter, Test Pit \#1 Layer 4. Comment: assoc artifacts include pottery, domesticated animals (based on tentative identification), an iron implement and late Stone age obsidian tools.

\section{B. North Sinai Peninsula}

Charcoal and ostrich egg samples were coll by $\mathrm{O}$ Bar-Yosef and J C Phillips in Jan 1973 (if not indicated otherwise) on Epi-Paleolithic (Mushabian) and Upper Paleolithic (Lagaman) sites and subm by J L Phillips, Dept Anthropol, Univ Illinois at Chicago Circle, Illinois.

\section{SMU-118. Lagama III d \\ $30,050 \pm 1240$ 28,100 вС}

Ostrich egg shell fragments at foot-hills of Gebel Lagama, part of 
Gebel Meghara $\left(30^{\circ} 46^{\prime} \mathrm{N}, 33^{\circ} 27^{\prime} \mathrm{E}\right)$ surface colln from an open-air site. Coll 1973 by I Gisis. Comments (OB-Y): site contained an Upper Paleolithic assemblage, characterized with numerous bladelets, burins, and scrapers. Related to Lagaman industry. (JLP): site has 2 horizons. Date is too old for either Epi-Paleolithic or UP V (Atlitian) element.

\section{SMU-172. Lagama VII 1st sample}

$34,170 \pm 3670$

32,220 вC

\section{SMU-185. Lagama VII 2nd sample}

$31,210 \pm 2780$

29,260 BC

Charcoal impregnated with silt, from total excavated area at foothills of Gebel Lagama in Gebel Meghara (30 $\left.46^{\prime} \mathrm{N}, 33^{\circ} 27^{\prime} \mathrm{E}\right)$. Site is sealed in an older dune with several sandy and silty layers above living floor. Coll by D O Henry in Feb and May 1974. Comments (OB-Y): typesite for Lagaman industry. Lithic assemblage is characterized by domination of El-Wad points and retouched bladelets. (JLP): given the standard deviation and the nature of the sample, the 2 dates fit with date of Lagama VIII (SMU-119). These dates are a little earlier than those obtained by Tixier from Ksar 'Akil, Lebanon, on similar Upper Paleolithic material.

\section{SMU-119. Lagama VIII}

$32,980 \pm 2140$

Ostrich egg shell fragments, surface colln from open air site at Gebel Lagama, Gebel Meghara (30 $\left.46^{\prime} \mathrm{N}, 33^{\circ} 27^{\prime} \mathrm{E}\right)$. Comments (OB-Y): typical lithic assemblage of Lagaman industry (defined as an Upper Paleolithic industry) very similar to Lagama VII with El Wad points or bladelets, scrapers, and burins. (JLP): date is a bit older than expected but fits relatively well with similar material from Ksar 'Akil, Lebanon.

\section{SMU-117. Mushabi I}

$13,310 \pm 100$

$11,360 \mathrm{BC}$

Ostrich egg shell fragments from surface colln in open-air site, Gebel Meghara $\left(30^{\circ} 37^{\prime} \mathrm{N}, 33^{\circ} 30^{\prime} \mathrm{E}\right)$. Comments (OB-Y): site provided a lithic assemblage which is one of a few that were defined as Mushabian. The Mushabian industry belongs to the Levantine Epi-Paleolithic and shows clear affinities with North Africa (La Movillah points, arched backed bladelets, etc). (JLP): coll at recently deflated dune. Date fits perfectly with stratigraphy and typology.

\section{SMU-171. Mushabi V}

$12,990 \pm 110$ $11,040 \mathrm{BC}$

Charcoal from Wadi Mushabi in Gebel Meghara $\left(30^{\circ} 37^{\prime} \mathrm{N}, 33^{\circ} 30^{\prime}\right.$ $\mathrm{E}$ ), from a living floor containing remains from several hearths 10 to $20 \mathrm{~cm}$ below present surface in fossil dune. Coll May 1974 by O Bar-Yosef. Comments (OB-Y): site contained a lithic assemblage defined as Mushabian and is therefore closely related to Mushabi I (SMU-117). (JLP): date fits well with stratigraphy of sites nearby and with typology. 


\section{REFERENCES}

Haynes, C V and Haas, Herbert, 1974, Southern Methodist University radiocarbon date list I: Radiocarbon, v 16, p 368-380.

Rainey, M, 1974, The Quaternary stratigraphy of the North Sulphur River: MS thesis, Southern Methodist Univ, Dallas, Texas, $28 \mathrm{p}$

Slaughter, B H and Hoover, B R, 1963, Sulphur River formation and the Pleistocene mammals of the Ben Franklin local fauna: Graduate Research Center Jour, v 31, p 132-148.

Valastro S Jr, Davis, E M, and Varela, A G, 1975, University of Texas at Austin radiocarbon dates X, Radiocarbon, v 17, p 52-98. 